\title{
AKSES INFORMASI BPJS KESEHATAN BAGI KELOMPOK MASYARAKAT BERKEBUTUHAN KHUSUS (STUDI PADA KELOMPOK DEAF)
}

\author{
Sinta Swastikawara \\ Jurusan Ilmu Komunikasi, FISIP, Universitas Brawijaya \\ J1 Veteran, Kota Malang, 65145 \\ E-mail: sintaswastika@ub.ac.id
}

\begin{abstract}
ABSTRAK
Penelitian ini bertujuan untuk mendeskripsikan akses informasi kelompok deaf atas informasi terkait BPJS Kesehatan. Penelitian ini dilakukan merujuk pada beberapa penelitian terdahulu yang telah melakukan pada kelompok deaf pada lingkup health literacy namun belum dilakukan penelitian terkait akses informasi asuransi kesehatan publik yang juga diperoleh kelompok ini. Penelitian ini dilakukan dengan menggunakan metode studi kasus. Hasil dari penelitian ini menunjukkan bahwa akses informasi kelompok deaf terkait BPJS Kesehatan masih menggantungkan pada keberadaan pendamping mereka. Upaya yang dilakukan oleh organisasi kesehatan masih berkisar pada pemberian brosur informasi maupun penjelasan melalui teknik tulisan tangan. Hal ini berimplikasi pada persepsi kelompok deaf atas BPJS Kesehatan yang dianggap masih kurang memenuhi kebutuhan mereka terkait informasi asuransi publik. Di sisi lain, kelompok deaf juga memandang bahwa tenaga kesehatan yang berada di bawah naungan BPJS Kesehatan harusnya paham dan mengerti tentang cara berkomunikasi yang tepat dengan mereka, sehingga tidak menimbulkan kecurigaan dan anggapan negatif pada tenaga kesehatan yang menangani mereka.
\end{abstract}

Kata Kunci: Akses Informasi, Deaf, BPJS Kesehatan, Berkebutuhan Khusus

\section{PENDAHULUAN}

Undang-Undang Nomor 8 tahun 2016 telah mengatur tentang hak yang diperoleh oleh difabel, termasuk diantaranya mengatur pula tentang hak atas memperoleh informasi terkait kesehatan. Hak tersebut tercantum dalam beberapa pasal Undang-Undang Nomor 8 Tahun 2016 diantaranya yaitu pasal 12 terkait Hak Kesehatan, pasal 73 terkait Bagian Kesehatan, dan pasal 124 terkait Bagian Komunikasi dan Informasi. UndangUndang Nomor 8 Tahun 2016 juga menjadi salah satu cerminan dari upaya dijalankannya Undang-Undang Nomor 14 Tahun 2008 tentang Keterbukaan Informasi Publik yang mewajibkan setiap institusi wajib memberikan informasi terhadap publik. Adapun kriteria terkait informasi publik tersebut adalah Informasi yang Wajib Disediakan dan Diumumkan Secara Berkala, Informasi yang Wajib Diumumkan secara Serta Merta, dan Informasi yang Wajib Tersedia Setiap Saat.

Sejalan dengan peraturan tersebut, maka menjadi konsekuensi yang mengikat bagi seluruh elemen dan instansi yang bergerak di bidang kesehatan untuk memberikan akses informasi yang mudah bagi difabel, termasuk diantaranya adalah BPJS Kesehatan. BPJS Kesehatan sebagai lembaga asuransi publik milik negara bertugas untuk memfasilitasi masyarakat dalam mengakses fasilitas kesehatan yang telah disediakan oleh pemerintah melalui 3 tingkat fasilitas kesehatan (https://bpjs-kesehatan.go.id, diakses pada 1 Mei 2018). Dengan tugas tersebut, maka BPJS Kesehatan menjadi salah satu lembaga yang paling banyak dibutuhkan informasinya oleh masyarakat. BPJS Kesehatan telah melakukan beberapa upaya dengan memberikan fasilitas berupa webiste, leaflet, poster hingga iklan layanan masyarakat yang dapat diakses oleh masyarakat luas untuk mengetahui fasilitas dan layanan yang diberikan oleh BPJS Kesehatan.

Penelitian tentang informasi kesehatan dan kaitanya dengan kelompok deaf telah banyak dikaji utamanya terkait hambatan yang ditemui terkait pemberian informasi kesehatan pada kelompok ini. Merujuk pada penelitian yang dilakukan oleh Naseribooriabadi, Sadoughi, dan Sheikhtaheri (2017) literature review yang dilakukan pada 73 jurnal mulai tahun 1987-2016 menunjukkan adanya beberapa pola terkait kebutuhan kelompok deaf dan informasi kesehatan yaitu literasi kesehatan yang tidak memadai, hambatan dan fasilitator untuk mengakses informasi kesehatan serta layanan kesehatan yang dapat diperoleh setiap orang dengan kondisi deaf. Hambatan bahasa ikut menjadi semakin kompleksnya permasalahan ini. Napier dan Kidd (2013) menunjukkan bahwa ketidaksamaan bahasa yang digunakan oleh kelompok deaf dengan bahasa yang digunakan oleh kelompok non-deaf pada akhirnya menciptakan jarak informasi sehingga membuat kelompok deaf "dipaksa" untuk memahami pesan kesehatan yang tidak mereka pahami bahasanya. 
Dalam beberapa penelitian yang lain, ditemukan bahwa ada beberapa metode yang dinilai efektif dalam menyampaikan informasi kesehatan kepada kelompok deaf. Penelitian yang dilakukan oleh Haricharan, Heap, Hacking dan Lau (2017) di wilayah Afrika Selatan menunjukkan bahwa layanan SMS (short message service) dinilai efektif dalam meningkatkan pengetahuan kelompok deaf terkait hipertensi dan cara hidup sehat. Selain itu, internet juga dianggap sebagai salah satu media yang dapat memenuhi kebutuhan informasi kelompok deaf. Hal ini diutarakan oleh Smith, MasseyStokes, dan Lieberth (2012) bahwa akses informasi yang dilakukan oleh remaja perempuan dengan kondisi deaf melalaui website berkisar pada kondisi fisik selama masa puber, aktivitas fisik dan nutrisi, dan hubungan.

Berkaca pada penelitian yang telah dilakukan sebelumnya yang masih banyak berkisar pada akses informasi kesehatan, maka penelitian ini berusaha mengkaji akses informasi yang dapat diperoleh kelompok deaf terkait informasi mengenai asuransi publik BPJS Kesehatan. Merujuk pada UU nomor 18 tahun 2016 mengenai hak difabel, maka menjadi hak kelompok deaf pula untuk dapat mengakses informasi terkait asuransi publik. Permasalahannya adalah apakah media yang sudah ada mampu menjawab kebutuhan informasi kelompok deaf.

Penelitian ini dilakukan berdasarkan research gap yang peneliti temukan pada penelitian atas kelompok deaf yang telah dilakukan sebelumnya. Penelitian yang telah dilakukan sebelumnya, masih melakukan pemusatan perhatian mereka pada kehadiran fasilitas fisik di tempat pelayanan kesehatan beserta probabilitas untuk mengakses layanan kesehatan (Firdaus dan Iswahyudi, 2010; Syukria dan Supriyanto, 2016), akses informasi terkait pelayanan kesehatan (Haryono dan Mas'udah, 2013; Smith, Massey-Stokes, dan Lieberth, 2012; Orsi, Margellos-Anast, Perlman, Giloth, dan Whitman, 2007); kampanye kesehatan (Sadler, Branz, Fager, Seegers, dan Shimasaki, 2012; Haricharan, Heap, Hacking dan Lau, 2017); kebutuhan komunikasi kelompok deaf dan hambatannya (Megan dan Magowan, 2014; Naseribooriabadi, Sadoughi, dan Sheikhtaheri, 2017; Napier dan Kidd, 2013). Oleh karena itu, penelitian ini hadir untuk memberikan pandangan lebih mendalam lagi terkait pengalaman yang dimiliki oleh kelompok deaf untuk mengakses informasi terkait asuransi kesehatan.

Dalam konteks penelitian ini, akses terhadap informasi asuransi kesehatan juga dianggap penting selain informasi atas layanan kesehatan yang bersifat fisik. Merujuk pada penelitian sebelumnya terkait kehadiran fasilitas fisik di tempat pelayanan kesehatan beserta probabilitas untuk mengakses layanan kesehatan bagi masyarakat deaf (Firdaus dan Iswahyudi, 2010; Syukria dan Supriyanto, 2016), akses informasi terkait pelayanan kesehatan bagi masyarakat deaf (Haryono dan Mas'udah, 2013; Smith, Massey-Stokes, dan Lieberth, 2012; Orsi, Margellos-Anast, Perlman, Giloth, dan
Whitman, 2007), maka penelitian ini hadir dengan melakukan tinjauan atas kedua hal ini secara bersamaan yaitu fasilitas informasi asuransi publik dan juga akses informasi asuransi publik. Tinjauan atas kedua hal ini didasarkan pada pandangan atas dibutuhkannya akses informasi yang jelas terkait asuransi publik bagi kelompok deaf, merujuk pada UU No. 8 tahun 2016 bahwa hak untuk memperoleh informasi kesehatan juga dimiliki oleh masyarakat difabel. Tidak hanya terkait informasi kesehatan semata, namun juga meliputi fasilitas kesehatan yang dapat mereka akses.

\section{RUANG LINGKUP}

Ruang lingkup dalam penelitian ini dibatasi dalam beberapa hal yang tertuang dalam cakupan permasalahan dan batasan penelitian. Selanjutnya, luaran dari hasil penelitian ini juga diarahkan untuk membangun saran selanjutnya bagi instansi yang terkait. Berikut adalah penjabaran ruang lingkup dalam 3 poin utama, yaitu:

1. Cakupan Permasalahan

Dalam penelitian ini, permasalahan yang dibahas mencakup akses yang diperoleh kelompok deaf terkait informasi BPJS Kesehatan. Lebih lanjut lagi, penelitian ini berusaha menggali tentang persepsi yang dimiliki oleh kelompok deaf terkait dengan akses informasi yang mereka miliki atas BPJS Kesehatan. Dengan demikian, penelitian ini akan banyak mengulas pada akses informasi baik yang bersifat online maupun offline terkait BPJS Kesehatan oleh kelompok deaf.

2. Batasan Penelitian

Penelitian ini dibatasi pada kelompok deaf saja, sehingga hasilnya tidak bisa dijadikan patokan bagi bentuk difabel yang lain. Selain itu, penelitian ini juga membatasi pada akses informasi yang diberikan BPJS Kesehatan, sehingga tidak membahas pada layanan kesehatan yang diberikan oleh BPJS Kesehatan.

3. Rencana Hasil yang Didapatkan

Rencana hasil yang akan didapatkan dalam penelitian ini adalah, dapat memetakan persepsi kelompok deaf terkait informasi asuransi kesehatan publik BPJS Kesehatan. Selain itu, penelitian ini juga diharapkan dapat dipetakannya kebutuhan bentuk informasi terkait asuransi publik BPJS Kesehatan bagi kelompok deaf, sehingga pemberian informasi dapat disampaikan dalam bentuk yang tepat dan terarah.

\section{BAHAN DAN METODE} dilakukan

Berikut disajikan bahan kajian dan metode yang

\subsection{Pendekatan Tradisional dan Kontemporer dalam Komunikasi Kesehatan}

Pendekatan tradisional dan kontemporer dalam komunikasi kesehatan merujuk pada peran teknologi komunikasi sebagai media penyampaian informasi 
kesehatan (Thomas, 2008). Pada pendekatan tradisional difokuskan pada penerapan pendekatan komunikasi kesehatan yang disesuaikan dengan kebutuhan target yang berbeda-beda dan bentuknya sederhana (misalkan penyebaran informasi dan rujukannya) hingga pada tataran yang lebih kompleks (misalkan inisiasi untuk melakukan perubahan perilaku).

Adapun ragam metode tradisional ini meliputi distribusi materi, informasi dan rujukannya, public relations, penggunaan komunikasi formal, penjangkauan komunitas, relasi dengan pemerintah, networking, sales promotion, iklan, personal sales, direct mail, social marketing, dan spokepersons (Thomas, 2008, h. 119132). Pada pendekatan kontemporer, peran teknologi komunikasi yang berbasis elektronik sangat memberikan peran besar karena terjadi pergeseran dari direct-toconsumer mengarah pada e-marketing campaigns (Thomas, 2008).

\subsection{Metode Penelitian}

Metode penelitian yang diterapkan dalam penelitian ini adalah metode studi kasus tipe single instrumental case study dimana peneliti berfokus pada sebuah isu, kemudian memilih salah satu kasus dengan batasan tertentu untuk mengilustraasikan kasus tersebut (Creswell, 2007). Teknik analisis data yang digunakan adalah categorigal agregation (Stake dalam Creswell, 2007, h. 163) di mana dalam teknik analisis ini peneliti diberikan ruang untuk mencari data dan menentukan makna yang relevan atas isu yang muncul. Dengan menggunakan teknik analisis data ini, maka setelah peneliti memperoleh data maka peneliti memetakan poin penting untuk digiring menjadi beberapa kategori dan diringkas menjadi beberapa tema (Creswell, 2007).

Wawancara dilakukan pada 5 orang deaf dengan identitas disamarkan. Keterlibatan 5 orang deaf ini didasarkan pada keterlibatan mereka selama mengakses layanan BPJS Kesehatan, baik di Fasilitas Kesehatan Tingkat 1 hingga 3 . Adapun identitas narasumber dalam penelitian ini telah disamarkan. Peneliti juga melakukan dokumentasi pada situs online BPJS Kesehatan sebagai pelengkap data dalam penelitian ini.

\section{PEMBAHASAN}

Pada pembahasan ini, peneliti akan membagi dalam beberapa bagian yang merujuk pada fokus penelitian yaitu hambatan akses informasi BPJS Kesehatan bagi kelompok deaf dan persepsi atas akses informasi BPJS Kesehatan bagi kelompok deaf.

\subsection{Hambatan Akses Informasi BPJS Kesehatan Bagi Kelompok Deaf}

Berdasarkan data yang telah diperoleh oleh peneliti, ditemukan data bahwa narasumber penelitian ini masih sering mendapatkan kesulitan ketika mengakses informasi terkait BPJS Kesehatan. Kesulitan yang ditemui oleh narasumber banyak berkaitan dengan ketidaktahuan mereka atas cara mengakses informasi
BPJS Kesehatan. Berikut adalah beberapa potongan wawancara terkait hal ini:

"belum pernah buka website BPJS. Saya tahu informasi BPJS dari orang orang sekitar" (NS, wawancara 10 Oktober 2018)

"informasi BPJS hanya dapat dari orang tua dan volunteer" (TH, wawancara 10 Oktober 2018)

"sudah lihat website tapi isinya tidak paham, hanya lihat alur saja” (SY, wawancara 13 Oktober 2018)

"BPJS tahu untuk berobat ke klinik, lihat brosur saja tapi bahasanya sulit paham" (KH, wawancara 15 Oktober 208)

"di klinik dan rumah sakit ada poster BPJS, tapi masih harus dibantu orang tua atau kalau tidak ada pendamping untuk bantu jelaskan agar bisa mandiri" (HF, wawancara 15 Oktober 2108)

Merujuk pada hasil wawancara di atas, hambatan yang dihadapi oleh kelompok deaf atas akses informasi BPJS Kesehatan banyak berkaitan dengan kurangnya pemahaman cara melakukan akses informasi BPJS Kesehatan secara online. Temuan ini didapatkan dari hasil data di atas bahwa kelompok deaf mengalami kesulitan ketika mengakses informasi terkait BPJS Kesehatan. Hal ini berlaku pada informasi yang sifatnya secara daring. Merujuk pada hal tersebut, peneliti juga telah melakukan dokumentasi terkait situs online BPJS Kesehatan.

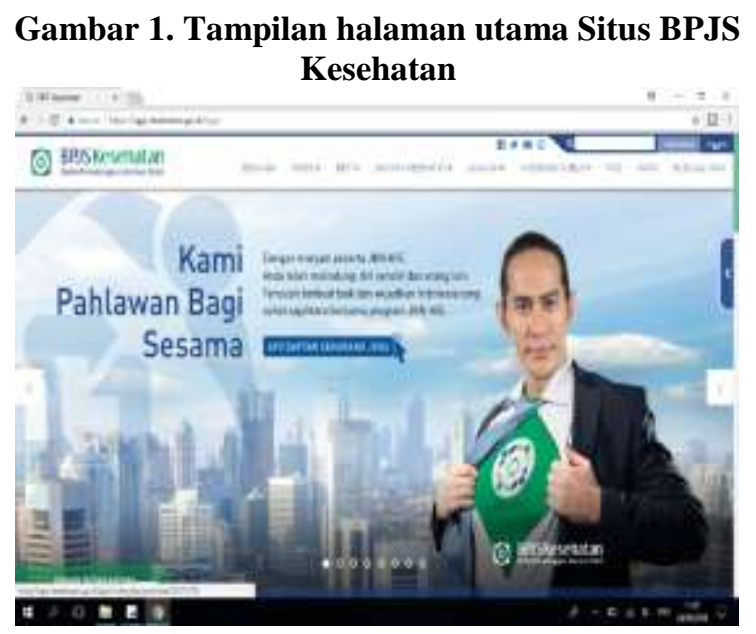

Gambar 2. Tampilan Informasi JKN Ada Dalam Aplikasi Mobile pada Situs BPJS Kesehatan

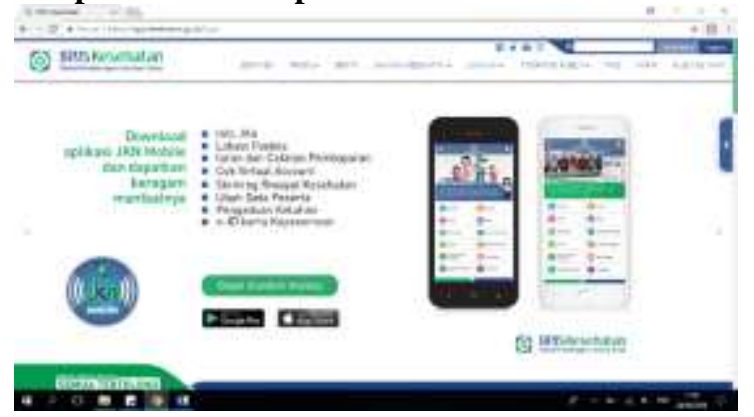




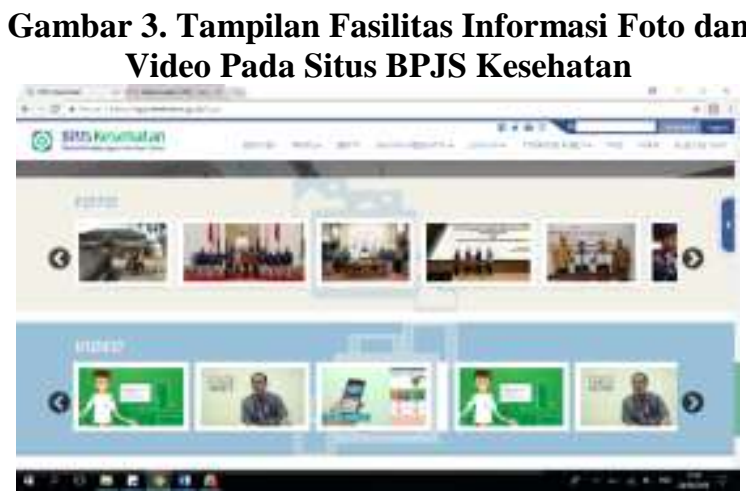

Pada dasarnya, merujuk pada Gambar 1, Gambar 2 dan Gambar 3 tampilan situs BPJS Kesehatan cukup ramah bagi pengguna internet, namun bagi kelompok deaf situs tersebut kurang familiar bagi mereka karena mereka menganggap ada bagian yang membingungkan ketika mereka sendiri yang mengakses. Hal ini dikaitkan dengan informasi yang ramah bagi kelompok deaf. Pada akhirnya, kelompok deaf lebih memilih menggunakan media yang sifatnya tradisional seperti poster dan brosur terkait BPJS Kesehatan untuk memperoleh informasi yang mereka butuhkan. Selain itu, penggunaan brosur lebih mudah mereka peroleh terutama ketika mereka sedang berada di fasilitas kesehatan.

Alternatif lain selain menggunakan media tradisional berupa poster dan brosur adalah dengan mengandalkan orang tua, pendamping, dan atau volunteer untuk membantu mereka dalam memahami informasi BPJS Kesehatan. Selain itu, mereka juga mengandalkan metode lain yaitu metode tulisan tangan ketika mereka berhadapan dengan tenaga kesehatan yang tidak paham tentang bahasa isyarat.

Penggunaan media online sebagai media untuk mencari informasi terkait informasi kesehatan dan cara mengakses layanan kesehatan sebenarnya menjadi salah satu solusi yang paling baru pada saat ini. Merujuk pada Wright, Sparks, O’Hair (h.185, 2013) bahwa "consumer can find a variety of websites sponsored by government organizations, such as the National Institute of Health (NIH) and the Center for Disease Control (CDC), and on-line medical journals, and they can even pose questions and receive information from healthcare specialists on some websites". Berdasarkan hal tersebut maka dapat disimpulkan bahwa sebenarnya akses informasi kesehatan dan layanan kesehatan secara online dapat menjadi solusi yang cukup baik. Namun, hal ini bertolak belakang dengan kondisi kelompok deaf yang menganggap bahwa informasi online tidak selalu membantu menjawab kebutuhan mereka.

Hal ini disebabkan karena fitur yang tidak ramah bagi kelompok deaf, terutama terkait konten yang termuat. Berkaitan dengan konten, maka hambatan yang ditemui oleh kelompok deaf adalah bahasa yang bukan menjadi bahasa asli mereka. Hal ini senada dengan dengan temuan Napier dan Kidd (2013) yang menunjukkan bahwa perbedaan bahasa tutur asli antara health provider yang menggunakan Bahasa Inggris dengan deaf yang menggunakan bahasa Auslan menjadi permasalahan utama sehingga yang harus dilakukan adalah mengubah konten informasi menjadi bahasa tutur asli kelompok deaf.

Dickson dan Magowan (2014) juga menyatakan bahwa "people whose first language is British Sign Language find contact with the NHS problematic". Hal ini menunjukkan bahwa, bahasa tutur asli kelompok deaf, baik berupa tulis dan oral, yang berbeda dengan bahasa asli kelompok non deaf menjadi permasalahan yang cukup pelik. Maka, dibutuhkan jembatan yang mampu menghubungkan antara kebutuhan kelompok deaf atas informasi yang dimiliki oleh kelompok non deaf.

\subsection{Persepsi Atas Akses Informasi BPJS Kesehatan Bagi Kelompok Deaf}

Berdasarkan data yang telah diperoleh oleh peneliti, ditemukan bahwa implikasi yang muncul akibat hambatan yang dihadapi oleh kelompok deaf atas akses informasi BPJS Kesehatan adalah persepsi mereka yang cenderung menilai bahwa BPJS Kesehatan masih kurang memenuhi kebutuhan mereka. Berikut adalah beberapa potongan wawancara terkait hal ini:

"Iya, pernah karena kurangnya informasi, sudah tanya-tanya ke orang disitu tapi dialihkan ke orang lain" (NS, wawancara 10 Oktober 2018)

"Iya, pernah sulit berkomunikasi dengan dokter karena saya Tuli, biasanya komunikasi dengan dokter pakai tulisan. Tapi saat dibaca, tulisan dokter tidak bisa dibaca . kadang kalau saya baca mulut dokter, sulit dibaca karena dokter bicara terlalu cepat. Saran , harusnya 1 ruangan ada 1 dokter dan 1 perawat, nanti perawat yang jelasin ke teman Tuli" (TH, wawancara 10 Oktober 2018)

"Dulu orangtua saya sudah menjelaskan ke dokter bahwa saya Tuli, sehingga dokter di klinik langganan saya sudah sadar bagaimana caranya berkomunikasi dengan saya. menurut saya, cara komunikasi dokter itu sudah baik." (SY, wawancara 13 Oktober 2018)

"Dokter salah mendiagonsa karena saya kesulitan komunikasi sehingga saya tidak jadi mengikuti ajuran dokter" (KH, wawancara 15 Oktober 208)

"Harus ada video tentang prosedur pendaftaran" (HF, wawancara 15 Oktober 2108)

Merujuk pada hasil wawancara diatas, menunjukkan bahwa persepsi atas akses informasi BPJS Kesehatan pada kelompok deaf mengarah pada layanan pemberian informasi pada mereka yang dianggap masih tidak memenuhi kebutuhan mereka. Informasi yang harusnya disediakan oleh BPJS Kesehatan, bagi kelompok deaf, harusnya disediakan dalam bentuk video alur yang menunjukkan tentang cara akses layanan dan apa saja yang harus disiapkan untuk mengakses layanan tersebut.

Di sisi lain, kelompok deaf memandang kemampuan health provider yang ada pada lingkup BPJS Kesehatan untuk menjelaskan informasi tentang kondisi kesehatan 
mereka harus lebih diasah lagi. Hal ini berkaitan dengan munculnya rasa percaya kelompok deaf terhadap penyedia informasi, dalam hal ini adalah kelompok health provider. Menimbulkan rasa percaya pada pasien menjadi nilai penting dalam konteks pemberian layanan kesehatan, termasuk diantaranya adalah informasi kesehatan.

Hal ini didukung oleh Orsi, Margellos-Anast, Perlman, Giloth, Whitman (2007) yang menyatakan bahwa akses terhadap deteksi kesehatan dini (terutama pada kanker) selayaknya diakses oleh deaf, namun yang menjadi permasalahan adalah etika, kualitas pelayanan yang diberikan, dan pendidikan kesehatan yang mengikuti pemberian informasi layanan kesehatan. Pemberian informasi kesehatan bagi kelompok deaf sesungguhnya sama pentingnya dengan pemberian informasi kepada kelompok non-deaf. Namun permasalahan yang muncul adalah, kemampuan para health provider atas skill komunikasi dengan mereka sangat rendah dan bahkan mereka merasa cenderung diabaikan.

Bentuk pengabaian ini dapat ditemukan dalam beberapa bentuk yaitu pelemparan tanggung jawab pemberian informasi kepada health provider lain, serta pemberian informasi yang tidak tepat bagi kelompok deaf dan mereka mengindikasikan sebagai bentuk pembohongan. Pelatihan atas hal ini dirasakan masih kurang bagi kelompok deaf sehingga dokter dan perawat masih sering gagap ketika harus menghadapi mereka.

Hal ini senada dengan yang diutarakan oleh Dickson dan Magowan (2014) terkait 5 poin utama permasalahan yang dihadapi oleh kelompok deaf yaitu rendahnya kemampuan komunikasi yang dimiliki oleh kelompok non deaf, perbedaan bahasa tutur antara kelompok deaf dan non deaf, rendahnya panduan bagi perawat dan dokter untuk berkomunikasi dengan kelompok deaf, rendahnya pelatihan dan pemahaman bagi dokter dan perawat atas kondisi kelompok deaf, dan dibutuhkannya penelitian lebih banyak terkait pengalaman kelompok deaf dalam mengakses layanan kesehatan.

Merujuk pada Thomas (2008), pendekatan komunikasi kesehatan secara tradisional dan kontemporer tidak akan selalu bisa dilakukan pada setiap kelompok orang. Pendekatan komunikasi kesehatan secara kontemporer yang berbasis teknologi komunikasi melalui internet tidak selalu tepat bagi kelompok deaf karena mereka menghadapi kendala besar terkait bahasa dan fitur yang ada. Pendekatan komunikasi secara tradisional di satu sisi juga menjadi penting bagi kelompok deaf karena melalui pendekatan ini membuat mereka melibatkan pendamping untuk menjelaskan kepada mereka. Namun di sisi lain, tidak dapat dipungkiri bahwa ada keinginan bagi mereka untuk bisa mandiri dan tidak bergantung pada pendamping. Oleh karena itu, pengelolaan materi informasi terkait BPJS Kesehatan harus diolah lebih mendalam termasuk juga sistem penyampaiannya.

\section{KESIMPULAN}

Akses informasi kelompok deaf terkait BPJS Kesehatan masih menggantungkan pada keberadaan pendamping mereka. Upaya yang dilakukan oleh organisasi kesehatan masih berkisar pada pemberian brosur informasi maupun penjelasan melalui teknik tulisan tangan. Hal ini berimplikasi pada persepsi kelompok deaf atas BPJS Kesehatan yang dianggap masih kurang memenuhi kebutuhan mereka terkait informasi asuransi publik. Di sisi lain, kelompok deaf juga memandang bahwa tenaga kesehatan yang berada di bawah naungan BPJS Kesehatan harusnya paham dan mengerti tentang cara berkomunikasi yang tepat dengan mereka, sehingga tidak menimbulkan kecurigaan dan anggapan negatif pada tenaga kesehatan yang menangani mereka.

\section{SARAN}

Media informasi terkait layanan kesehatan bagi kelompok deaf harus dipertimbangkan lagi terkait pengelolaannya. Hal ini berkaitan dengan penggunaan bahasa dan media yang digunakan dalam pembuatannya. Selain itu, diperlukannya pelatihan bagi health provider terkait kemampuan mereka untuk menghadapi kelompok deaf sehingga akan menekan rasa ketidakpercayaan yang timbul.

\section{DAFTAR PUSTAKA}

Dickson, M., \& Magowan, R. 2014. Meeting Deaf Patient's Communication Needs. Nursing Times, 110 (49), 12-15.

Firdaus, F., \& Iswahyudi, F. 2010. Aksesibilitas dalam Pelayanan Publik Khusus untuk Masyarakat dengan Kebutuhan Khusus. 6 (3). 1-16.

Haricharan, H J., Heap, M., Hacking, D., \& Lau, Y K. 2017. Health Promotion Via SMS Improves Hypertension Knowledge for Deaf South Africans. BMC Public Health, 17 (663), 1-17.

Haryono, T S H., Kinasih, S E., \& Mas'sudah, S. 2013. Akses dan Informasi bagi Perempuan Penyandang Disabilitas dalam Pelayanan Kesehatan Reproduksi dan Seksualitas. Masyarakat, Kebudayaan dan Politik, 26 (2), 65-79.

Naseribooriabad, T., Sadough, F., \& Sheikhtaher, A. 2017. Barriers and Facilitators of Health Literacy among D/deaf Individuals: A Review Article. Iran J Public Health, 46 (11), 1465-1474.

Napier, J., \& Kidd, M R. 2013. English Literacy as a Barrier to Health Care Information for Deaf People

Who Use Auslan. Australian Family Physician, 42 (12), 896-899.

Orsi, J M., Anast, H M., Perlman, T S., Giloth, B E., \& Whitman, S. 2007. Cancer Screening Knowledge, Attitudes, and Behaviors Among Culturally Deaf Adults: Implications for Informed Decision Making. Cancer Detection and Prevention, 31 (2007), 474-479. 
Sadler, G R., Branz, P., Fager, M., Seegers, S., \& Shimasaki, S. 2012. Health Promotion via Deaf Friendly Ministries. J Canc Educ, 27 (2012), 606611.

Smith, C E., Massey-Stokes, M., \& Lieberth, A. 2012. Health Information Needs of D/Deaf Adolescent Females: a Call to Action. American Annals of the Deaf, 157 (1), 1-9.

Syukria, O A., dan Supriyanto, S. 2016. Determinan Pemanfaat Puskesmas Pada Anak Penyandang Disabilitas. Jurnal Administrasi Kesehatan Indonesia, 4 (1), 37-47.

Thomas, R K. 2008. Health Communication. New York: Springer.

Wright, K B; Sparks, L; O'hair, H D. 2013. Health Communication in the $21 \mathrm{st}$ Century. United Kingdom: Wiley Blackwell. 